\title{
Recombinant NY-ESO-1 Protein
}

National Cancer Institute

\section{Source}

National Cancer Institute. Recombinant NY-ESO-1 Protein. NCI Thesaurus. Code C38143.

A genetically eng ineered synthetic protein, Recombinant NY-ESO-1 Protein (Cancer-

Testis Tumor Antigen Family) elicits strong humoral and cellular immune responses to NY-ESO-1-expressing cancers and is used to produce specific vaccines to increase the immune response ag ainst tumors. NY-ESO-1 epitopes presented by human HLA are recognized by CD4(+) T lymphocytes in patients with NY-ESO-1-expressing melanoma. $(\mathrm{NCl04})$ 